\title{
Voter Participation in the Absence of the 1965 Voting Rights Act
}

\author{
Keith Parker*, Dora Tilles, Clifton Brown, Dawn Brown McGlotten
}

Sociology and Criminal Justice, Florida A\&M University, Tallahassee, the United States

\author{
Email address: \\ keith.parker@famu.edu (K. Parker) \\ ${ }^{*}$ Corresponding author
}

\section{To cite this article:}

Keith Parker, Dora Tilles, Clifton Brown, Dawn Brown McGlotten. Voter Participation in the Absence of the 1965 Voting Rights Act. International Journal of Education, Culture and Society. Vol. 6, No. 5, 2021, pp. 159-166. doi: 10.11648/j.ijecs.20210605.11

Received: July 29, 2021; Accepted: September 13, 2021; Published: September 27, 2021

\begin{abstract}
In June 2013, the Supreme Court ruled in Shelby County v. Holder that states with a history of racial discrimination no longer needed to approve proposed changes to their voting procedures with the federal government. The court ruled that the coverage formula was based on 40-year-old data that was not applicable to current needs. Thus the 2016 presidential election was the first in 50 years without the full protections of the Voting Rights Act. The objective of this paper is to examine the changes in voter turnout between the 2012 and the 2016 national elections due to the changes in the Voting Rights Act. Using data from the voter file vendor Catalist and information from the U.S. Census Bureau, this paper examined changes in turnout rates for different racial/ethnic groups between 2012 and 2016. The findings indicated (1) African American turnout declined substantially; (2) white turnout increased considerably; (3) Latino American turnout increased, and (4) in the key swing states of Michigan, Wisconsin, and Pennsylvania, fluctuations in voter participation were especially strong. Voter enthusiasm and perceived voter suppression efforts had a huge impact on voter turnout. In addition, not being able to identify with candidates or properly researching candidates' political goals hampered the desire to vote, especially in Black Americans.
\end{abstract}

Keywords: Voting Rights, Voter Suppression, Voter ID Laws, Voter Disenfranchisement

\section{Introduction}

The Constitution of the United States grants American citizens the sacred right to vote in local, state and national elections [19, 29-32, 46, 47, 59]. The aim of the 1965 Voting Rights Act (hereafter 1965 VRA) was to insure that no one, at any level of government, could impede people from registering to vote or actually vote because of their race or ethnicity [31]. Although the 1965 VRA was initially viewed as a pathway to voting booths and elected office holding, it was subsequently viewed as the predecessor and gateway to advancements in many other aspects of life [12]. "Voting is the foundation stone for political action," Reverend Martin Luther King, Jr. wrote just months before passage of the 1965 VRA (1965, p. SM26).

According to numerous authors [5-6, 15, 19, 25, 29], the 1965 VRA was one of the most significant and effective pieces of legislation passed in $20^{\text {th }}$ century America. Passage and enforcement of the 1965 VRA removed decades-old barriers (i.e., literacy tests, poll taxes and the use of separate ballot boxes) that had made it challenging for Southern black people to register to vote and vote. Southern states ${ }^{1}$ which had employed literacy tests and other voter suppression tactics saw black voter registration rates increase an average of $67 \%$ between 1964 and 1968, from 33.8 to 56.5 percentage points $[15,64,73]$. In contrast, Southern states which did not deploy literacy tests and other forms of voter suppression tactics reported an average increase of roughly $19 \%$, from 60 to 71.4 percentage points, in black voter registration over the same period of time (see [15, 64, 73], for further discussion). Passage and enforcement of the 1965 VRA resulted in economic and social mobility, enfranchisement, and an increase in black office holding [12, $23,29,43,73,76]$.

In a June 25, 2013 decision, the United States Supreme Court ruled by a 5-to-4 vote that Section 4(b) of the 1965 VRA was unconstitutional because the coverage formula was

1 The states of Alabama, Arkansas, Florida, Georgia, Louisiana, Mississippi, North Carolina, South Carolina, Tennessee, Texas, and Virginia. 
based on forty year old data and thus making it no longer responsive to present-day needs and therefore an impermissible burden on the constitutional principles of federalism and equal sovereignty of the states [42, 69, 70]. Although the Supreme Court did not strike down Section 5, without the Section 4(b) provision of the 1965 VRA no jurisdiction will be subject to Section 5 preclearance unless Congress enacts a new coverage formula $[2,42,70]$.

Shelby County v. Holder (2013) was a landmark U. S. Supreme Court case regarding the constitutionality of several provisions of the Voting Rights Act of 1965: Section 5, that requires certain states and local governments to obtain federal preclearance before implementing any new changes to their voting laws or practices; and Section 4(b), which contains the coverage formula that determines which jurisdictions are subjected to preclearance approval due to their histories of discrimination in voting $[2,42,70]$.

Despite the U.S. Supreme Court's decision in Shelby County v. Holder (2013) the 1965 VRA victories are far from complete and time will reveal their lasting effects $[10,17,27$, $32,34,39,56,67]$. Consequently, more research focusing on the expansion of the franchise and the impact of Shelby County v. Holder is needed. The purpose of this study was to examine changes in voter turnout rates for different racial/ethnic groups between the 2012 and 2016 national elections.

\section{Literature Review}

The successes of the 1965 VRA represent one of America's greatest achievements of democracy [5, 6, 34, 59]. Most notably, the 1965 VRA ended racially motivated tactics Southern states had used to stifle the power of the minority voting electorate $[5,6,22,51,73,74]$. By eliminating obstacles to taking part in local and national elections, the 1965 VRA made it possible for increased voter participation among African Americans and other minorities [3, 4, 29, 50, 53, 75, 76] and led to increased African American and other minorities' participation, representation and office-seeking opportunities [5, 6, 9, 49].

Past studies reported the 1965 VRA contributed significantly to minority participation in the growth and expansion of state and local governments $[15,31,34,40,55$, $58,61]$. Past studies also reported black voter registration and black voter participation increased significantly following passage of the 1965 VRA [7, 8, 13, 16, 43, 48, 63, 72].

Passage and enforcement of the 1965 VRA dismantled historic cultural, political, social and economic barriers (e.g., literacy tests, oral interpretations of the constitution, payment of taxes, and demonstrations of good moral character) which had made it difficult for black people of the South to register and vote since the $1890 \mathrm{~s}[11,20,29,36,40,55,58,73]$. To the contrary, research reported that prior to the 1965 VRA, state and local governments provided minimal information and public service activities about political participation to large segments of society [21, 45].

Another important feature of the 1965 VRA was the designation of a city, county or state government as a covered jurisdiction if it implemented any discriminatory practice (e.g., literacy tests, oral interpretations of the constitution, payment of taxes) or if the voting registration rate or voting turnout rate among the voting population in the 1964 presidential election was lower than $50 \%$ [23, 31, 33, 65]. Cascio and Washington (2014) also reported the 1965 VRA prohibited discrimination in voting procedures and required selected jurisdictions to receive preclearance approval from the U.S. Department of Justice for any proposed change in the electoral procedure.

According to several studies [14, 28, 54, 71], the 1965 VRA was so successful between 1965 and 2005 that discussions of the Voting Rights Act of 1965 shifted from enfranchisement of registration and voting to questions of representation and the creation of majority and minority voting districts. Other studies (most notably [25, 41, 49, 66] reported the shift away from enfranchisement might not have been so problematic if the 1965 VRA were applicable only to African Americans. Numerous studies reported American Indians, Hispanics and Asian Americans continued to have noticeably lower rates of voter registration and participation than black and White populations $[1,38,52,57,60,68]$. For instance, Jamieson et al. (2001) observed only 25 percent of Asian and Pacific Islanders and 28 percent of the Latino voting age population participated in the 2000 presidential election, while 60 percent of voting age whites and 54 percent of voting age blacks voted. In the 2008 presidential election, one thought to represent the height of minority political participation, numerous studies [3, 24-26, 78] reported Latino and Asian turnout rates were at least eight percentage points behind the participation rates of whites and African Americans.

\section{Data}

\section{Individual-Level Turnout by Race/Ethnicity}

The turnout data used in this research are extracted from Catalist, LLC $^{2}$. Catalist, LLC is a data vendor for political campaigns. Catalist collected data on over 185 million registered voters across the 50 states, including the District of Columbia as of July 2011. Catalist obtains the registered voter listing from each state then organizes the data in a manner suitable for campaign activities. In addition to the individual level that is noted by election officials', Catalist also includes state provided indicators of individual level participation. ${ }^{3}$ This comprehensive nature of the collected

\footnotetext{
${ }^{2}$ See http://www.catalist.us. Detailed information about the database and vendor may be found in Ansolabehere and Hersh $(2012,2014)$. While Catalist generally leans toward progressive political organizations, the data used in this analysis are not likely to be biased in a partisan manner as Catalist acquires the full voter file from each state. At the time of the study, Virginia restricted the use of voter turnout records; thus, I do not include Virginia in my results. Catalist, LLC is not responsible for the analyses and interpretations presented in this study.

33 Catalist organizes individual records by state. For individuals who move across states, Catalist maintains a separate registration record for each person in both the "new" and the "old" state. As a result, turnout figures accurately reflect the voting population in an election at time $t$ despite the fact that some registrants may have moved, reregistered, and voted elsewhere for $\mathrm{t}+1$.
} 
data allows for a more accurate turnout figure then general survey estimates. National totals are derived from the same state level data used by Catalist, but Catalist's figures are not subject over reporting. For the 2006, 2008, and 2010 general elections, Catalist's figures were underestimated by less than $1 \%$ of the official count of ballots. Estimates from the Current Population Survey [18], ${ }^{4}$ which is generally considered a superior survey in comparisons to other surveys $[38,62]$, had a substantial great margin due to misreporting and the handling of survey non-responses [35].

Catalist records voter's full name, address, date of birth, gender, and vote history, which is provided by state voter registries. Past studies have noted the southern states spotted history of recording the race/ethnicity of registrants $[44,77]^{5}$ Catalist's recording of full name includes first middle, and last name matching. To predict the race/ethnicity of all registered voters, Catalist additionally provides, through a contract with CPM ethics, census block contextual data, commercial information, and registrant age. ${ }^{6}$ The result is that virtually every voter is predicted as either non-Hispanic White, Black, Latino, Asian, or Native American.

This research utilizes Catalist's estimates of race for registered voters for both the 2012 and 2016 national elections. To calculate turnout rates, the denominator used is an estimate of the citizen voting age population (CVAP) by race in November 2012 and November 2016 respectively. Catalist used the Census Bureau's Population Estimates Program data to calculate the registered voter's age population in each state by race. To remove the (often substantial) noncitizen population for each racial/ethnic group, the American Communities Survey information on citizenship rates was used.

\section{Findings}

Change in Voter Turnout Rates by Race/Ethnicity, 2012 and 2016

The findings reported in the first section of this study focused on changes in voter turnout rates during the 2012 and 2016 national elections between racial/ethnic groups. Our findings reported the national voter turnout rates for racial/ethnic groups changed noticeably from 2012 to 2016. As reported in Figure 1, the voter turnout rate among whites, the racial/ethnic group most loyal to Candidate Trump, increased by 2.4 percentage points from 2012 to 2016 . The findings shown in Figure 1 also reported increased voter turnout rates among Latino and Asian voters from 2012 to 2016; an increased voter turnout rate of 3.8 percentage points

\footnotetext{
${ }^{4} \mathrm{~A}$ full comparison of turnout as recorded in the Catalist database, official counts of ballots cast, and CPS (2010) estimates may be found in the supporting information.

${ }^{5}$ These states are Alabama, Florida, Georgia, Louisiana, North Carolina, and South Carolina. Mississippi and Tennessee do not require voters to list their race but provide space for this purpose on the registration form.

${ }^{6}$ The proprietary method used by Catalist and CPM Ethnics is rooted in wellunderstood principles of individual race prediction (Elliott et al. 2008). As noted in Ansolabehere and Hersh (2012), Catalist placed second in a national namematching contest. A (limited) set of information regarding the algorithm used by CPM Ethnics may be found at http://cpm-technologies.com/cpmEthnics.html.
}

among Latinos; and an increased voter turnout rate of 3.0 percentage points among Asian American. Our findings reported a very sharp contrast in the voter turnout rates among African Americans, the racial/ethnic group most loyal to Candidate Clinton and the Democratic Party, from 2012 to 2016. As illuminated in Figure 1, the voter turnout rate among African American declined by a staggering 4.7 percentage points. In sum, our findings reported (1) White voters were enthusiastic about the 2016 national election and showed up in increased turnout rates at the polls, (2) voter participation rates among Latino and Asian American groups, who generally vote for democratic candidates, increased noticeably during the four-year timeframe, and (3) Black voters were unenthusiastic about the 2016 election and many former voters did not participate in the 2016 election.

Change in African American and White Voter Turnout in Selected States, 2012 and 2016

\section{Change in turnout rates by race (2012 to 2016)}

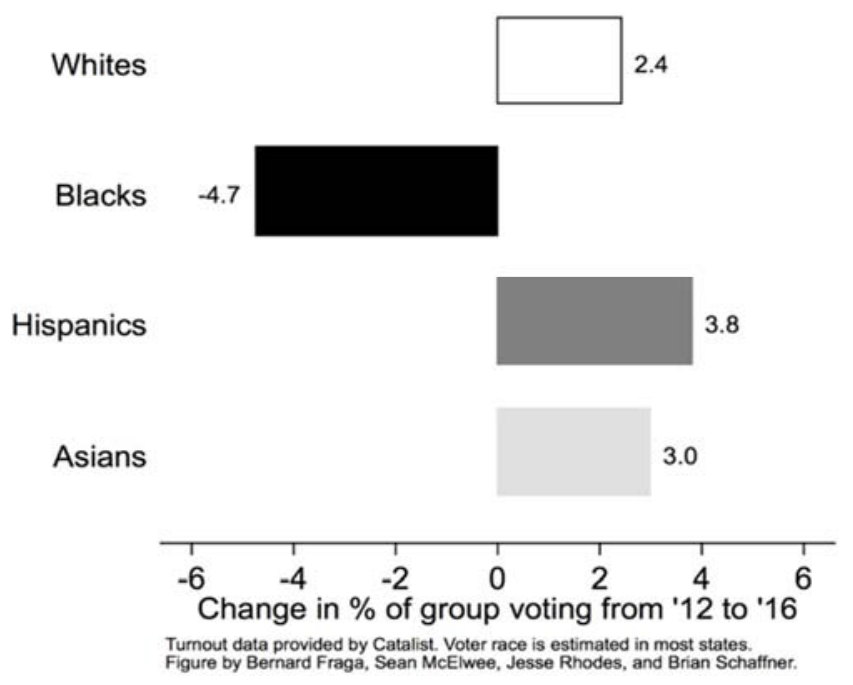

Figure 1. Changes in Turnout Rates, by Race, 2012 to 2016.

The findings reported in Figure 2 listed the states where at least three percent of the population was African American and changes in African American and White voter turnout rates between 2012 and 2016. Our findings revealed (1) with one lone exception, Delaware, voter turnout rates among African Americans declined, (2) in the very important Midwestern battleground states of Michigan and Wisconsin, the voter turnout rate among African Americans declined by more than 12 percentage points, (3) in the battleground states of Ohio and Pennsylvania, the voter turnout rates among African Americans declined by 7.5 and 2.1 percentage points, respectively. Many Southern states (notably Alabama, Arkansas, Missouri, North Carolina, Mississippi, Tennessee and South Carolina) reported at least a five-percentage point decline in African American voter turnout rates. In contrast, voter turnout rates among whites increased in every state except Ohio, Arkansas, Michigan, Mississippi, and Wisconsin between 2012 and 2016. In the very important 
Midwestern battleground states of Michigan and Wisconsin, the voter turnout rate among whites declined 2.6 percentage points and 1.0 percentage points, respectively. Also, in the battleground state of Ohio, the voter turnout rates among whites declined by 1.3 percentage points.

\section{Change in turnout rates of blacks and whites by state (2012 to 2016 )}



Figure 2. Changes in Black-White Turnout Rates, 2012 - 2016.

In the critical battleground state of Florida, White voter turnout increased 3.5 percentage points and Black turnout dropped 4.0 percentage points. In conclusion, the findings in Figure 2 reported (1) an increased turnout voter rate among whites except for Ohio, Arkansas, Michigan, Mississippi, and Wisconsin between 2012 and 2016, and (2) except for Delaware, voter turnout rates among African Americans declined from 2012 to 2016.

Change in Hispanics and White Voter Turnout in Selected States, 2012 and 2016

Data in Figure 3 reported changes in Hispanic and White voter turnout rates between 2012 and 2016. Our findings reported Hispanic voter turnout rates increased by more than 2.5 percentage points in seven states: Arizona, California, Connecticut, Florida, Illinois, New York and Texas. In three states (California, Illinois and Texas), the Hispanic voter turnout rate increased greater than white voter turnout. In California, the Hispanic voter turnout rate increased by 3.8 percentage points compared to 2.9 percentage points for white voters. Similarly, in Illinois, the Hispanic voter turnout rate increased by 9.8 percentage points compared to 4.4 percentage points for white voters. The Hispanic voter turnout rate in Texas increased by 4.9 percentage points compared to 3.7 percentage points for white voters. Our findings also reported, in the critical battleground state of Florida, the Hispanic voter turnout rate increased by 5.4 percentage points compared to 3.5 percentage points for white voters. The finding reported the Hispanic voter turnout rates declined slightly in the states of New Mexico and Rhode Island, $0.4 \%$ and $2.1 \%$, respectively.

\section{Change in turnout rates of Hispanics and whites by state (2012 to 2016)}

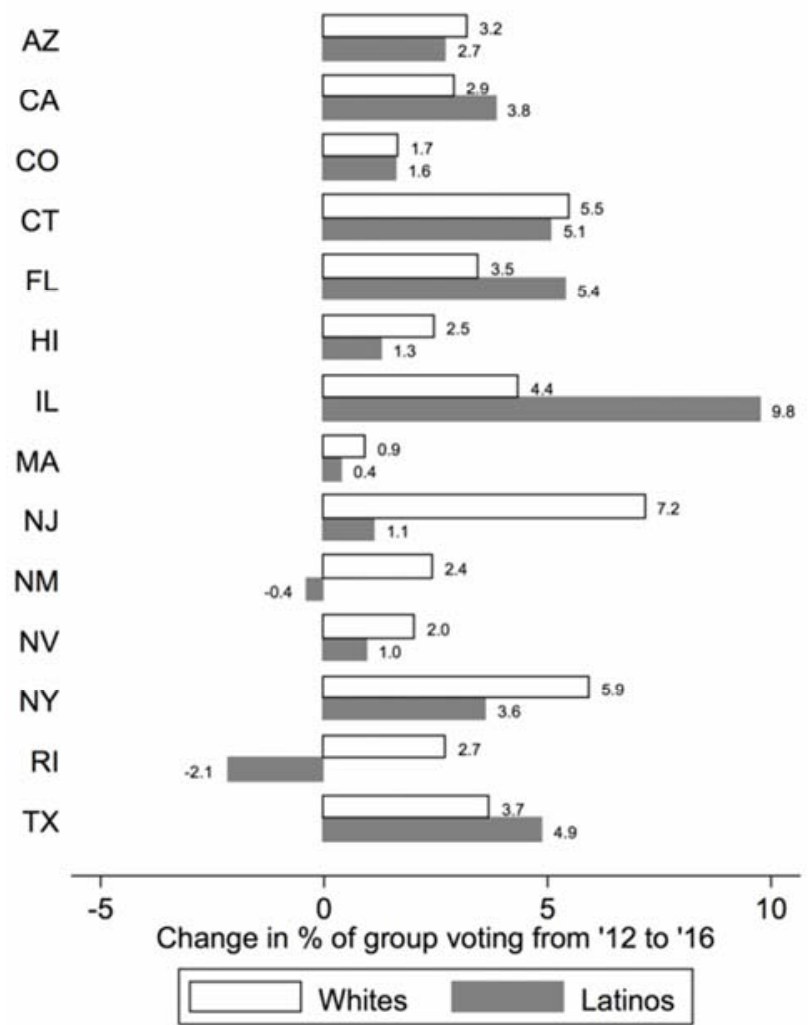

Turnout data provided by Catalist. Voter race is estimated in most states. Figure by Bernard Fraga, Sean McElwee, Jesse Rhodes, and Brian Schaffner.

Figure 3. Changes in Turnout Rates, Hispanics and Whites. 
The findings revealed white voter turnout rates increased slightly in all of the states listed in Figure 3. A closer examination of the findings in Figure 3 showed a noticeable increase of at least 2.5 percentage points in white voter participation rates in the states of Arizona, California, Connecticut, Florida, Illinois, New Jersey, New York, Rhode Island and Texas. All of the states listed in Figure 3 reported an increase in white voter turnout rates. In sum, the findings in Figure 3 reported increased voter turnout rates between 2012 and 2016 among white voters in each of the listed states. With exceptions of New Mexico and Rhode Island, our findings reported increased voter turnout rates between 2012 and 2016 among Hispanic voters in the listed states.

\section{Conclusions}

The purpose of this research was to examine changes in voter participation between different racial/ethnic groups during the 2012 and 2016 national elections. Our findings, like earlier findings [24-26, 78] revealed noticeable differences in voter turnout rates between racial/ethnic groups from 2012 to 2016 . Specifically, our findings reported Black voter turnout decreased approximately five percentage points from 2012 to 2016, resulting in the lowest Black turnout since the 2000 national election. As noted by Frey (2017), the very low turnout among Black voters in 2016 was notable and disappointing because, in large part, the 2012 national election marked the first time since records were kept Black voter turnout rates were higher than White voter turnout rates.

Questions asked by individuals were (1) Why did Black voter turn rates decrease between 2016 over 2012, (2) Why did White voter turn rates increase between 2016 over 2012, (3) Why did Hispanic voter turn rates increase between 2016 over 2012, (4) Why did Asian voter turn rates increase between 2016 over 2012, and (5) would a larger Black voter turnout made a difference in the states Candidate Clinton did not win?

The answer to the first question revolves around voter enthusiasm and perceived voter suppression efforts. Black voters were less enthusiastic about the 2016 election and decided not to participate in rates comparable to the previous national elections. Studies have found minority voters are more likely to turnout when candidates seeking offices establish a close relationship with their communities or when a minority candidate is on the ballot (see $[3,4,25,75]$, for a discussion on the role of race in voter turnout). In contrast, findings $[25,34,49]$ have shown Black voters to be likely to perceive the requirement of photo identification, the reduction in early voting days, changes in the location of voting locations, and changes in number of hours polling places are open as attempts to suppress their opportunities to vote. As reported by Kirchubel (2016), the Brennan Center for Justice found that precincts with larger numbers of African-American and Latino voters had fewer voting machines and fewer poll workers, and thus, longer voting lines and longer waiting times than precincts with larger numbers of white voters. Similarly, a 2012 New York Times/CBS study showed 18 percent of Democratic voters waited more than half an hour to vote, compared to 9 percent of Republican voters (see [47]). Finally, studies indicated the ruling in the Shelby County v. Holder (2013) landmark United States Supreme Court case granted communities with histories of voter discrimination, voter intimidation and voter suppression practices the unchecked license to create barriers and obstacles to voting $[2,42,70]$.

Pertaining to the questions 2-4 several studies, including this study, reported increased voter turnout rates among white, Latino and Asian voters during the 2016 national election when compared to the between 2012 national election. Sanchez and Barreto (2016) reported Hispanic voters turned out early and in slightly high numbers in 2016 compared to 2012. The reasons for the increased turnout, according to Sanchez and Barreto (2016) and Fraga et al. (2017), were due to effectively mobilization activities by the Clinton campaign organization and anti-Mexican and antiimmigrant comments made by Candidate Trump during the campaign season. Similarly, the Pew Research Center survey (2016), Sanchez and Barreto (2016), Fraga et al. (2017 and Lopez et al. (2016), reported key policy issues among registered Latino voters (e.g., immigration, the economy, education and health care), high levels of anxiety and fear of a Trump presidency, and Latino enthusiasm about voting were energizing forces behind increased Latino voter registration and participation in the 2016 Presidential election,

An increase in voter participation among Asian Americans in the 2016 Presidential election, when compared to the 2012 national election, occurred across the board in key states being targeted by both presidential campaigns. AALDEF (2017) reported Candidate Clinton's support among AsianAmerican voters was very pronounced, four-in-five (80 percent) to one-in-five (20 percent) for Candidate Trump. Moreover, strong Asian support for Candidate Clinton centered on support for stricter gun-control laws; an overhaul of immigration laws that included a path to citizenship; attention on historic language barriers; and laws protecting LGBT people from discrimination in employment, education, housing and public accommodations (see [1] and [50] for a detailed discussion of the most important issues AsianAmerican voters wanted Candidates Clinton and Trump to talk about and now the Trump administration and Congress to work on).

White voter participation in the 2016 national election was only slightly higher than it was in the 2012 presidential election [57]. As noted by Mellnik et al. (2017), Candidate Trump and other GOP office-seekers did a much better job of energizing and sparking their base than Candidate Clinton and Democratic candidates. When we compare 2016 and 2012 turnout rates in the states of Michigan, Wisconsin, and Pennsylvania, we see similar turnout rates among white voters. However, in the same states, we observe an average drop of nine points among Black voters. Thus, one can surmise that shifts in just a few tenths of a point in voter 
turnout rates made a significant difference in the outcome of the 2016 U.S. presidential election.

\section{Discussion}

More than fifty years after passage of the 1965 Voting Rights Act, the United States of America still reports noticeably gaps in political participation between Americans. The findings presented here illuminated differences in voter turnout rates in the 2012 and 2016 Presidential elections. For example, overall White voter turnout in 2016 was up roughly $2.5 \%$ over the 2012 turn out rate. Similar increases in voter participation rates were reported for Hispanic and Asian voters, $3.8 \%$ and $3.0 \%$, respectively. Conversely, Black voter participation declined between 2012 and 2016.

The reasons for these changes appear to be cultural, political and logistical, with lower voter enthusiasm among Black voters and sustained or higher voter enthusiasm among White, Asian and Hispanic voters. Additionally, newly enacted and perceived impediments to voting played a significant role in many states. In North Carolina, for example, where a federal appeals court accused Republicans of a surgical assault on Black turnout and Republican-run election boards curtailed early-voting sites, Black turnout was down 16 percent. White turnout, however, was up 15 percent. Similar changes in voter turnout rates were reported in many states and most specifically in the swing states of Michigan, Wisconsin, and Pennsylvania.

The disappointing Black voter turnout in the 2016 presidential election foreshadowed a larger and more intractable problem for the Democratic Party and party officials to consider in the post-Obama era. One of the biggest challenges or opportunities the Democratic Party must confront in future elections is whether Mr. Obama's absence (or other high-ranking Black officials) from the party platform will depress Black voter enthusiasm and participation. Another challenge or opportunity the Democratic Party must address is how party dynamics (e.g., social and economic isolation, historical and continued racial segregation of black communities, lack of voter enthusiasm, and identity politics) shape Black politic views and participation.

While the above challenges and opportunities are real and must be addressed by political party officials, a confluence of factors contributed to the decline in Black turnout rates during the 2016 presidential election. One factor which must be considered is the voter suppression tactics made possible by the Shelby v. Holder (2013) decision, a decision that rescinded key protections in the 1965 Voting Rights Act. Other factors which must be considered and thoroughly discussed center around the absence of traditional Black leaders, Black institutions and the very noticeable absence of the first Black president of the United States during the 2016 Presidential campaign season. Finally, participating in the 2016 Presidential election and local elections was a privilege, obligation and constitutional right all Americans should have taken seriously and participated in. However, the most recent Presidential election, unlike past elections, did not seem to be taken as seriously as warranted until the day it was over. American voters, especially Black voters, should have done a better job of sifting through fake news reports, misinformation, and hoaxes and participated in the 2016 Presidential election.

\section{Declaration}

An earlier version of this paper was presented at the 2017 meeting of the Mid-South Sociological Association. Chattanooga, TN, October 18-21. Data used in this study were made available by the voter file vendor Catalist and information from the U.S. Census Bureau. The collector of the original data bears any responsibility for the interpretations presented here. All correspondences concerning this paper should be addressed to Keith D. Parker (keith.parker@famu.edu), Department of Sociology and Criminal Justice, Florida A\&M University, Tallahassee, FL.

\section{References}

[1] AALDEF. (2017). The Asian American Vote 2016: A Report by the Legal Defense and Asian American Education Fund. New York, NY.

[2] Barnes, R. (2013). Supreme Court stops use of key part of Voting Rights Act. Washington Post, June 25, 2013. Washington, DC.

[3] Barreto, M. A. (2010). Ethnic Cues: The Role of Shared Ethnicity in Latino Political Participation. Ann Arbor, MI: University of Michigan Press.

[4] Barreto, M. A., Segura, G. M., \& Woods, N. D. (2004). The Mobilizing Effect of Majority-Minority Districts on Latino Turnout. American Political Science Review, 98, 65-75.

[5] Berman, A. (2013). Conservatives Take Aim at Voting Rights (Voting Rights Act of 1965). The Nation, 296, 11- 17.

[6] Berman, A. (2015). Give Us the Ballot: The Modern Struggle for Voting Rights in America. New York: Farrar, Straus and Giroux.

[7] Black, M. (1978). Racial composition of congressional districts and support for federal voting rights in the American South. Social Science Quarterly, 59, 435-45.

[8] Bullock, C. S. (1981). Congressional voting and the mobilization of a black electorate in the South. Journal of Politics, 43, 662-682.

[9] Bullock, C. S., \& Gaddie, R. K. (2009). The Triumph of Voting Rights in the South. Norman, OK: University of Oklahoma Press.

[10] Burns, M. J. (2012). Shelby County v. Holder and the Voting Rights Act: Getting the Right Answer with the Wrong Standard. Catholic University Law Review, 62, 227-252.

[11] Burton, O. V., Finnegan, T. R., McCrary, P. \& Loewen, J. W. (1994). South Carolina. In Quiet Revolution in the South: The Impact of the Voting Rights Act, 1965-1990, C. Davidson, Bernard Grofman (Eds.). Princeton: Princeton University Press, 21-37. 
[12] Button, J. W. (1989). Blacks and Social Change: Impact of the Civil Rights Movement in Southern Communities. Princeton, NJ: Princeton University Press.

[13] Campbell, B. (1977). Partisan loyalties of southerners. Journal of Politics, 39, 730-761.

[14] Canon, D. (1999). Race, Redistricting and Representation: The Unintended Consequences of Black Majority Districts. Chicago, IL: University of Chicago Press.

[15] Cascio, E. U., \& Washington, E. (2014). Valuing the vote: the redistribution of voting rights and state funds following the Voting Rights Act of 1965. Quarterly Journal of Economics, $129,379-433$

[16] Castle, D., \& Stanley, H. W. (1982). Partisan realignment in the South: making sense of scholarly dissonance. Paper presented at the Southern Political Science Association Convention, Atlanta, GA, October 28-30.

[17] Cox, K. (2014). The Voting Rights Act under Review: Shelby County v. Holder and the Consequences of Change. Wayne Law Review, 60, 493-513.

[18] Current Population Survey. 2010. Voting and Registration. http://www.census.gov/hhes/www/socdemo/voting/

[19] Davidson, C. (1994). The Recent Evolution of Voting Rights Law Affecting Racial and Language Minorities. In Quiet Revolution in the South: The Impact of the Voting Rights Act, 1965-1990, C. Davidson, Bernard Grofman (Eds.). Princeton: Princeton University Press, 21-37.

[20] Davidson, C., \& Grofman, B. (1994). Quiet Revolution in the South: The Impact of the Voting Rights Act, 1965-1990. Princeton University Press.

[21] Donohue III, J. J., Heckman, J. J., \& Todd, P. E. (2002). The Schooling of Southern Blacks: The Roles of Legal Activism and Private Philanthropy, 1910-1960. Quarterly Journal of Economics, 117, 225-268.

[22] Endersby, J., \& Menifeld, C. E. (2000). Representation, Ethnicity and Congress: Black and Hispanic Representatives and Constituencies. In Black and Multiracial Politics in America, Yvette Alex-Assensoh and Lawrence J. Hanks (Eds.). New York: New York University Press, pp. 257-72.

[23] Filer, J. E., Kenny, L. W., \& Morton, R. B. (1991). Voting Laws, Educational Policies, and Minority Turnout. Journal Law and Economics, 34, 371-393.

[24] Fraga, B. L., McElwee, S., Rhodes, J., \& Schaffner, B. (2017). Why did Trump Win? More Whites-and fewer Blacks-actually voted. The Washington Post, May 8. https://www.washingtonpost.com/news/monkeycage/wp/2017/05/08/why-did-trump-win-more-whites-andfewer-blacks-than-normal-actuallyvoted $/$ utm term $=.7613576 \mathrm{a} 405 \mathrm{a}$

[25] Fraga. B. L. (2016). Candidates or Districts? Reevaluating the Role of Race in Voter Turnout. American Journal of Political Science, 60, 97-122.

[26] Frey, W. H. (2017). Census Shows Pervasive Decline in 2016 Minority Voter Turnout. The Avenue, https://www.brookings.edu/blog/theavenue/2017/05/18/census-shows-pervasive-decline-in-2016minority-voter-turnout/
[27] Greenbaum, J., Martinson, A., \& Gill, S. (2014). Shelby County v. Holder: When the Rational Becomes Irrational. (Civil Rights at a Critical Juncture: Confronting Old Conflicts and New Challenges). Howard Law Journal, 57, 811-867.

[28] Grofman, B., \& Davidson, C. (1992). Controversies in Minority Voting: The Voting Rights Act in Perspective. Washington, DC: Brookings Institution.

[29] Grofman, B., \& Handley, L. (1998). Voting Rights in the 1990s: An Overview. In Race and Redistricting in the 1990s, Bernard Grofman, (Ed.) New York: Agathon Press, 69-79.

[30] Guinier, L. (1994). The Tyranny of the Majority: Fundamental Fairness in Representative Democracy. New York The Free Press.

[31] Harada, M. (2012). The Voting Rights Act of 1965 and Strategic Policy Making in the South. State Politics \& Policy Quarterly, 12, 456-482.

[32] Hauer, M. (2014). Shelby County v. Holder: Why Section 5 of the Voting Rights Act is Constitutional and Remains Necessary to Protect Minority Voting Rights under the Fifteenth Amendment. Vermont Law Review, 38, 1027-1043.

[33] Heckelman, J. C. (1995). The Effect of the Secret Ballot on Voter Turnout Rates. Public Choice, 82, 107-24.

[34] Hopps, J. G., \& Bowles, D. D. (2015). A Response to Shelby County, Alabama v. Holder: Energizing, Educating and Empowering Voters, Phylon, 52, 1-23.

[35] Hur, A., \& Achen, C. H. (2013). Coding Voter Turnout Responses in the Current Population Survey. Public Opinion Quarterly, 77, 985-93.

[36] Husted, T. A., \& Kenny, L. W. (1997). The Effect of the Expansion of the Voting Franchise on the Size of Government. Journal of Political Economy, 105, 54-82.

[37] Jamieson, A., Shin, H. B., \& Day, J. (2001). U.S. Census Bureau, Current Population Reports, Series PPL-152. Voting and Registration in the Election of November 2000. Washington, DC: U.S. Government Printing Office.

[38] Jang, S. (2009). Get Out on Behalf of Your Group: Electoral Participation of Latinos and Asian Americans. Political Behavior, 31, 511-535.

[39] Johnston, C. (2015). Proportional Voting Through the Elections Clause: Protecting Voting Rights Post-Shelby County. UCLA Law Review, 62.

[40] Jones, D. B., Troesken, W., \& Walsh, R. (2012). A Poll Tax by Any Other Name: The Political Economy of Disenfranchisement. NBER Working Paper No. w18612.

[41] Jones-Correa, M. (2005). Language Provisions Under the Voting Rights Act: How Effective Are They? Social Science Quarterly, 86, 549-564.

[42] Kealing, J. (2013). U.S. Supreme Court strikes down key provision of Voting Rights Act. Public Radio International. Retrieved 8, July 2013.

[43] Keech, W. R. (1968). The Impact of Negro Voting. Chicago: Rand McNally.

[44] Keele, L. Shah, P., White, I., \& Kay, K. (2014). Black Candidates and Black Turnout: A Study of Mayoral Elections in the New South. Paper presented at the Midwest Political Science Association Annual Meeting, Chicago, IL. 
[45] Key, V. O. [(1949) 1984]. Southern Politics in State and Nation. New York: University of Tennessee Press.

[46] King Jr., M. L. (1965). Civil Right Number No. 1: The Right to Vote. New York Times, March 14, SM26.

[47] Kirchubel, M. (2016). Voter suppression tactics in action. Daily Republic, March 28, page A8.

[48] Knickrehm, K. M., \& Bent, D. (1988). Voting Rights, Voter Turnout, and Realignment: The Impact of the 1965 Voting Rights Act. Journal of Black Studies, 18, 283-296.

[49] Krogstad, J. M., \& Lopez, M. H. (2017). Black voter turnout fell in 2016, even as a record number of Americans cast ballots. Pew Research Center, May 12, 2017.

[50] Lee, T. (2016). Asian American Voters In The 2016 Election. The Blog. https://www.huffingtonpost.com/latinodecisions/asian-american-voters-in_b_12637044.html

[51] Leighley, J., \& Vedlitz, A. (1999). Race, Ethnicity, and Political Participation: Competing Models and Contrasting Explanations. Journal of Politics, 61, 1092-1114.

[52] Lien, P. (1994). Ethnicity and Political Participation: A Comparison between Asian and Mexican Americans. Political Behavior, 16, 237-264.

[53] Lopez, M. H., Gonzalez-Barrera, A., Krogstad, J. M., \& Lopez, G. (2016). Democrats Maintain Edge as Party 'More Concerned' for Latinos, but Views Similar to 2012. Pew Research Center.

[54] Lublin, D. (1997). The Paradox of Representation: Racial Gerrymandering and Minority Interests in Congress. Princeton, NJ: Princeton University Press.

[55] Margo, R. (1990). Race and Schooling in the South, 1880 1950: An Economic History. Chicago, IL: University of Chicago Press.

[56] Marinaccio, V. (2014). Protecting Voters' Rights: The Aftermath of Shelby v. Holder. Whittier Law Review, 35, 531-557.

[57] Mellnik, T., Muyskens, J., Soffen, K., \& and Clement, S. (2017). Politics Analysis That Big Wave of Less-Educated White Voters? It Never Happened. The Washington Post, May $10,2017$.

[58] Naidu, S. (2012). Suffrage, Schooling, and Sorting in the PostBellum U.S. South. NBER Working Paper No. w18129.

[59] Parker, K. D., Murty, K. S., Lakshminath, A., \& Tilles, D. O. (2016). Racial Microaggressions and Voter Suppression Tactics in the United States. Paper presented at the 6th Annual National Civil Rights Conference, June 20-22, 2016, Meridian, MS.

[60] Pew Research Center. (2017). Black Voter Turnout Rate Declined Sharply in 2016, Dropping Below that of Whites. http:/www.pewresearch.org/fact-tank/2017/05/12/black-voterturnout-fell-in-2016-even-as-a-record-number-of-americanscast-ballots/

[61] Platt, M. B. (2015). An Examination of Black Representation and the Legacy of the Voting Rights Act. Phylon, 52, 87-107.

[62] Rocha, R. R., Tolbert, C. J., Bowen, D. C., \& Clark, C. J.
(2010). Race and Turnout: Does Descriptive Representation in State Legislatures Increase Minority Voting? Political Research Quarterly, 63, 890-907.

[63] Rodgers Jr., H. R., \& Bullock III, C. S. (1972). Law and Social Change: Civil Rights Laws and Their Consequences. New York: McGraw-Hill.

[64] Rosenberg, G. N. (2008). The Hollow Hope: Can Courts Bring About Social Change. University of Chicago Press.

[65] Rusk, J. G., \& Stucker, J. J. (1978). The Effect of the Southern System of Election Laws on Voting Participation: A Reply to V. 0. Key, Jr. In The History of American Electoral Behavior, edited by Joel H. Silbey, Allan G. Bogue, and William H. Flanigan. Princeton, NJ: Princeton Univ. Press.

[66] Sanchez, G., \& Barreto, M. A. (2016). In record numbers, Latinos voted overwhelmingly against Trump. We did the research. The Washington Post, November 11, https://www.washingtonpost.com/news/monkeycage/wp/2016/11/11/in-record-numbers-latinos-votedoverwhelmingly-against-trump-we-did-theresearch/?utm_term $=.11753 \mathrm{f} 51 \mathrm{f} 4 \mathrm{fl}$

[67] Schwinn, S. D. (2013). Shelby County v. Holder: What it Means for the Voting Rights Act. Social Education, 77, 243247.

[68] Shaw, D., de la Garza, R. O., \& Lee, J. (2000). Examining Latino Turnout in 1996: A Three-State, Validated Approach. American Journal of Political Science, 44, 332-40.

[69] Shelby County v. Holder, 570 U.S. 2. (2013). https://www.supremecourt.gov/opinions/12pdf/1296 6k47.pdf.

[70] Shelby County v. Holder. https://www.oyez.org/cases/2012/12-96.

[71] Swain, C. (1993). Black Faces, Black Interests: The Representation of African Americans in Congress. Cambridge: Harvard University Press.

[72] Terchek, R. J. (1980). Political Participation and Political Structures: The Voting Rights Act of 1965. Phylon, 41, 25-35.

[73] Valelly, R. M. (2004). The Two Reconstructions: The Struggle for Black Enfranchisement. Chicago, IL: University of Chicago Press.

[74] Verba, S., \& Nie, N. H. (1972). Participation in America: Political Democracy and Social Equality. New York: Harper and Row.

[75] Washington, E. (2006). How Black Candidates Affect Voter Turnout. Quarterly Journal of Economics, 121, 973-98.

[76] Washington, E. (2012). Do Majority-Black Districts Limit Blacks' Representation? The Case of the 1990 Redistricting. Journal of Law and Economics, 55, 251-274.

[77] Whitby, K. J. (2007). The Effect of Black Descriptive Representation on Black Electoral Turnout in the 2004 Elections. Social Science Quarterly, 88, 1010-23.

[78] Wilson, R. (2017). Voter turnout dipped in 2016, led by decline among blacks. The Hill http://thehill.com/homenews/campaign/332970-voter-turnoutdipped-in-2016-led-by-decline-among-blacks 